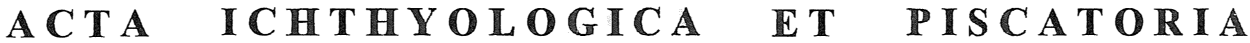

Andrzej KORONKIEWICZ

\section{SIZE AND MATURITY DIFFERENCES BETWEEN TRAWL AND JIGGER CAUGHT SHORT-FINNED SQUID ILLEX AR GENTINUS (CEPHALOPODA: OMMASTREPHIDAE)}

\author{
PORÓWNANIE STRUKTURY DLUGOŚCIOWEJ I DOJRZALOŚCI \\ PLCIOWEJ KALMARÓW ILLEX ARGENTINUS (CASTELLANOS, 1960) \\ ZLOWIONYCH WEQDAMI I WEOKIEM
}

\author{
Sea Fisheries Institute, Świnoujście Branch, Poland
}

The present study was undertaken to cast some light on this methodological problem as well as to determine how representative the materials used in biological research on Illex argentinus have been so far. It is contended that trawling, as a forced sampling technique, provides a sample representative of an Illex population, while jigging, as a harvesting/sampling method based on behavioural responses of the squids, is selective. The squids were obtained during commercial trawling and jigging operations undertaken on 4-15, 24-25 and 28-31 March and 2, 7-11 April 1992 in the Illex-rich Falkland Interim Conservation Zone. Differences among basic biological parameters of the population (e.g. length and maturity frequency) indicate that jigger-caught Illex were larger than those caught by trawling by $7 \mathrm{~mm}$ (males) and $12 \mathrm{~mm}$ (females) on the average. Jiggers affected the behavioural esponses of the squids and resulted in higher frequencies of larger individuals. Those frequencies being higher by: $13.5 \%$ in $25-28 \mathrm{~cm}$ long males, the general range being $19-28$ $\mathrm{cm} ; 21.2 \%$ in $26-30 \mathrm{~cm}$ long females, the general range being $16-30 \mathrm{~cm}$. Differences between the jigger-and trawl-caught squid lengths can be described with a linear regression. The jigger-caught Illex were more mature than those caught with the trawl by $0.8 \%$ (males) and $5.1 \%$ (females, on the average. 


\section{INTRODUCTION}

Research on biology of Illex argentinus on the Falkland - Argentine shelf is closely linked to the commercial exploitation of the squids there. The research, carried out since 1980, has been based on commercial operations of various vessels. The study materials were obtained both by jigging and trawling. When frozen squids were analysed following their delivery to a Polish laboratory, the type of gear used was frequently unknown and/or disregarded. It was only when the work was carried out on board a vessel employing both techniques that gear-dependent differences in the squid size became apparent [Wolnomiejski 1992].

The present study was undertaken to cast some light on this methodological problem as well as to determine how representative the materials used in biological research on I.argentinus have been so far. It is contended that trawling, a forced sampling technique, provides a sample representative of an Illex population, while jigging, as a harvesting/sampling method based on behavioural responses of the squids, is selective. Due to the lack of data on selectivity and catch ability of trawls and jiggers used to harvest the Illex, both in the Polish and foreign literature, the statistical treatment of data pertaining to the population structure of I.argentinus caught with jiggers vs. those caught with trawls is given a particular attention.

\section{I.ARGENTINUS AS A TARGET SPECIES}

Which of the two harvesting techniques is used to catch the Illex depends on the life cycle stage and behavioural responses of the species. I.argentinus, a shelf-oceanic squid, inhabits waters overlying the continental shelf and slope off Argentina and the Falkland Islands. The species' range is limited to the north by the subtropical convergence (about $38 \mathrm{~S}$ ) and bordered by subantarctic convergence (about $53 \mathrm{~S}$ ) to the south [Castellanos 1960]. The region of mass concentrations of the species, on the other hand, extends from $40 \mathrm{~S}$ to the Falklands [Sato 1980; Hatanaka 1985; Martinez et al. 1991; Koronkiewicz and Porębski 1990].

Juvenile and immature individuals of I.argentinus are very abundant in the shallow, less than $120 \mathrm{~m}$ deep, water overlying the northern part of the Argentine shelf [Brunetti 1980; Arkhipin and Scherbich 1991]. In January-February, the juveniles perform south-bound feeding migrations on the shelf to feed on the lobster-krill, i.e., larvae of the crustacean Munida gregaria, the basic diet component of the Illex. In March-April/May, the crustaceans are very abundant on the northern slopes of the Falkland shelf [Harrison 1932; Koronkiewicz 1985; Wolnomiejski 1985]. When there are no lobster-krill aggregations, the squids disperse over the whole Falkland shelf and migrate further south, to the Beauchene Island, and feed on concentrations of the Loligo gahi squids [Koronkiewicz 1991; Wysokinski 1992]. While migrating, I.argentinus can be harvested with both jiggers (at night) and trawls (during the day), mainly in the southern Argentine fishing grounds $\left(45-47^{\circ} \mathrm{S}, 140-160 \mathrm{~m}\right.$ depth) and in the northern, Illex-rich sector of the Falkland grounds (160-250 m deep).

In May, the maturing and mature squids begin to migrate back to their spawning grounds. They still form aggregations, in the near-bottom slope water as depths of 400-800 m and even deeper. They do not perform diumal vertical migrations and feed predominantly on concentrations of the Myctophidae fish. At this stage of their life cycle, they can be harvested with a trawi only. They are caught in the southern $\left(45-47^{\circ} \mathrm{S}, 400-600 \mathrm{~m}\right.$ deep) and northern $\left(42^{\circ} \mathrm{S}, 650-850 \mathrm{~m}\right)$ Argentine grounds [Koronkiewicz 1986; Koronkiewicz and Porębski $1990]$. 


\section{MATERIALS AND METHODS}

The squids were obtained during commercial trawling and jigging operations undertaken on 4-15, 24-25 and 28-31 March and 2 and 7-11 April 1992 in the Illex-rich FICZ sector of the Falkland shelf. To ensure comparability of the material, only the catches effected in the same area, with jiggers at night and with trawls the following day, are considered. The grounds operated on were of a similar depth range (145-160 m).

The oceanic-type jiggers, 25 per set, were used. The trawl type was 103/256, the trawl codend consisting of three layers of netting. Additionaily, a fine-mesh inset (the so-called krill net) was applied, which deprived the codend of its selectivity and eliminated the selectivity-related losses. The comparative analysis was made on 19 jigger and 23 trawl samples, the samples containing 30-100 squids. A total of 3274 I.argentinus individuals were examined: 1764 males (1048 from trawl and 716 from jigger catches) and 1510 females (600 trawled and 910 jigged).

Following the ICES/ICNAF recommendations on morphometric measurements, the squid size was determined from the dorsal length measured to $1.0 \mathrm{~cm}$, rounded off to the lower value [Holden and Rait 1974].

Sexual maturity of the squids was assessed with the 6-stage scale developed by Lipinski [1979]: stage 1, juvenile; stage 2, immature; stage 3, preparatory; stage 4, maturing; stage 5, mature; stage 6 , spent.

The data were subject to a statistical treatment, aided by the Statgraphics computer software; the options "Point estimators" and "Interval estimation and hypothesis testing" were used [Oktaba 1974]

The squid length distribution is presented as frequencies of males and females, caught with trawls and jiggers, in different length classes. The "averaged" frequencies were obtained by pooling all the samples. Mean lengths in pairs of samples were compared with Student's t test, the pairs involving daytime trawl catch-nighttime jigging catch and the same nighttime jigging catch-trawl catch of the following day.

To analyse the sexual maturity patterns in the squid population, an index of mean maturity stage of males and females was used, the index being a weighed average of frequencies of all maturity stages of each sex.

\section{RESULTS}

\section{Size structure}

Fig. 1 shows curves representing length distributions of I.argentinus caught with the trawl and jiggers. The separate curves for males and females are shown in Fig. 2 and 3, respectively.

Values of Chi-square obtained for all the variables tested were below the critical values at the confidence level of $p=0.05$, thus indicating the normal distribution of the data. The following table shows the results of the test.

\begin{tabular}{|l|c|c|}
\hline \multicolumn{1}{|c|}{ Variable } & Chi-square & Degrees of freedom \\
\hline trawl-caught Illex & 43.71 & 30 \\
jigger-caught Illex & 46.17 & 40 \\
trawl-caught males & 21.02 & 12 \\
jigger-caught males & 32.13 & 21 \\
trawl-caught females & .14 .81 & 8 \\
jigger-caught females & 36.22 & 24 \\
\hline
\end{tabular}




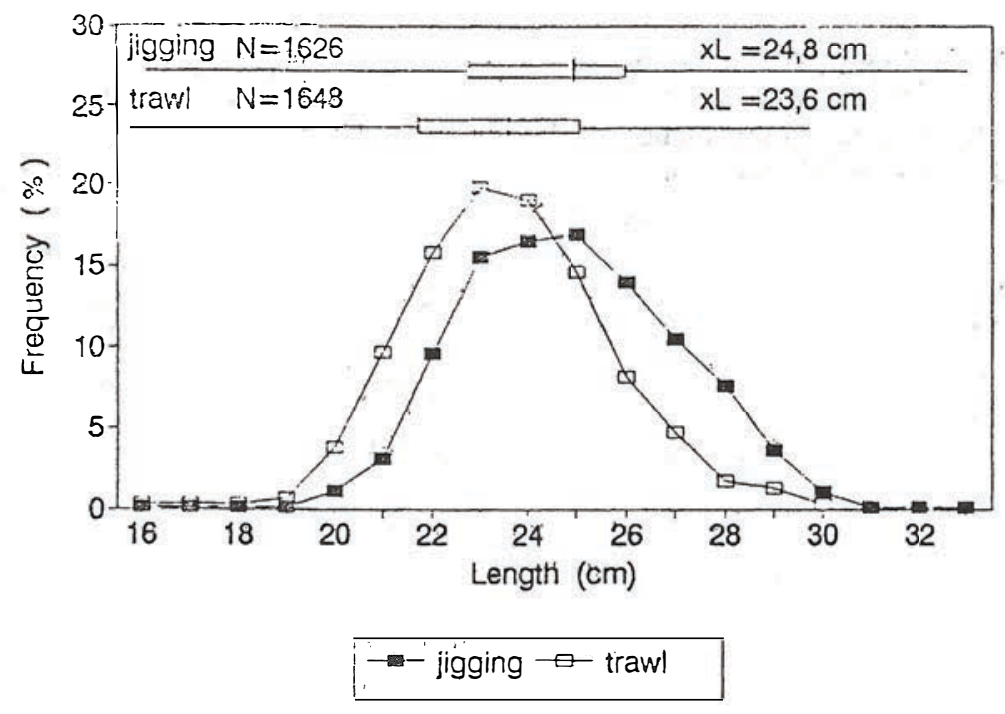

Fig. 1. Length distribution of trawl and jigging caught Illex argentinus

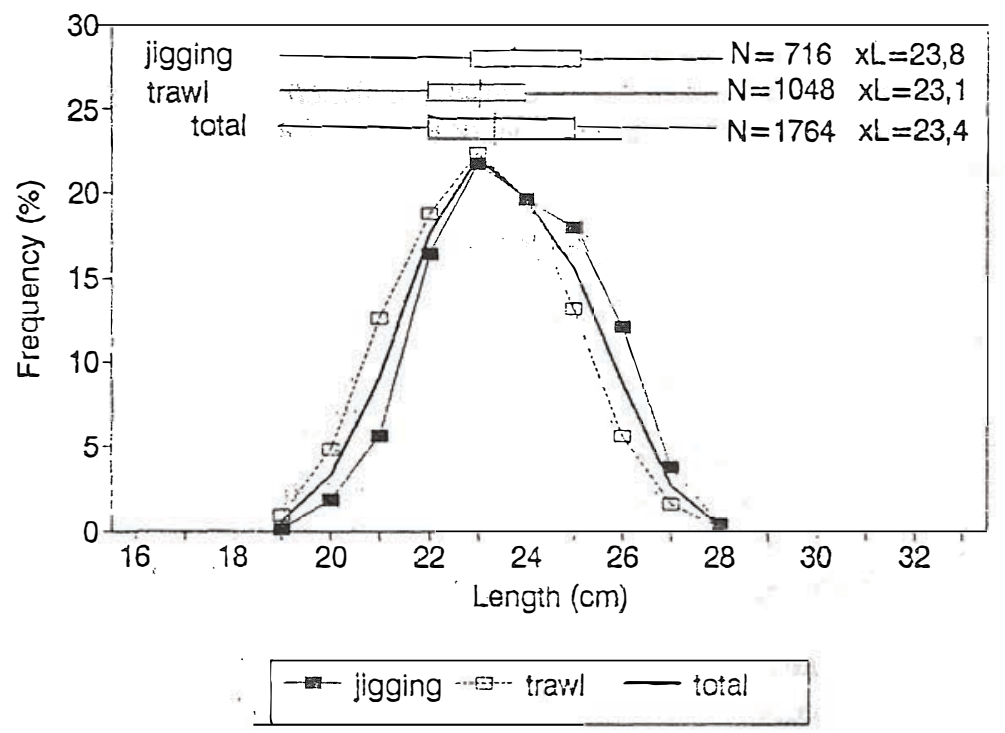

Fig. 2. Length distribution trawl and jigging caught Illex argentinus males 
The frequency curves of the trawl-and jigger-caught squids differ mostly in the span of the $x$ axis they cover (Fig.1).

The trawl catches curve ranges within $16-30 \mathrm{~cm}$. the distribution being symmetrical with the maximum frequency: at the (central) $23 \mathrm{~cm}$ length class. On the other hand, the jigger catches curve extends from: 16-3.3 cm and includes larger length classes; the maximum frequency is found in the (central) $25 \mathrm{~cm}$ length class. The peak is somewhat flattened due to small frequency differences between classes of $23-25 \mathrm{~cm}$ The jigger-caught I.argentinus were larger, by $1.2 \mathrm{~cm}$ on the average, than those caught by trawl (Fig. 1).

Similar patterns. involving trawl catches with smaller and jigger catches with larger individuals, can be found in frequency curves of males and females (Fig. 2 and 3). The two male curves have much in common: the same length range $(29-28 \mathrm{~cm})$ and almost overlapping peaks of the maximum frequencies (Fig. 2). The trawl-caught females ranged in size from $16-30 \mathrm{~cm}$, the maximum frequency falling on the (central) $24 \mathrm{~cm}$ length class. The jigger-caught female length range begins in the $16 \mathrm{~cm}$ class, too, but it is much wider, ending in the $33 \mathrm{~cm}$ class (Fig. 3). Differences between frequencies of trawl-and jigger-caught males and females are plofted in Fig. 4, while frequency differences with respect to the average frequencies (pooled trawl and jigger samples) of males and females are shown in Figs 5 and 6, respectively. The trawl catches had a higher frequency of smaller squids, $19-24 \mathrm{~cm}$ long males and $16-25 \mathrm{~cm}$ long females, while larger squids $(25-28 \mathrm{~cm}$ long males and $25-33 \mathrm{~cm}$ long females) were more frequent in the jigger catches. The pooled difference in frequencies concerns $13.5 \%$ of males and $21.2 \%$ of females, the length difference being $7 \mathrm{~mm}$ for males and $12 \mathrm{~mm}$ in females (Figs 2-4). The differences become still lower when the parameters are compared with the "average" data. The pooled difference in frequencies concern then $7.0 \%$ of males and $10.6 \%$ of females (Figs 5 and 6 ). As a result, compared to the average male length of $23.5 \mathrm{~cm}$, the trawl-caught males were smaller by $3 \mathrm{~mm}(1.3 \%)$ on the average, while those caught with jiggers were larger by $4 \mathrm{~mm}(1.7 \%)$ on the average (Figs 2 and 5). Compared to the average female length of $25.2 \mathrm{~cm}$, the trawl-caught females were smaller by $7 \mathrm{~mm}(2.3 \%)$ on the average, while those caught with jiggers were larger by $5 \mathrm{~mm}(2.0 \%)$ on the average (Figs 3 and 6).

The next step of the statistical treatment involved application of Student's t test the null hypothesis of mean lengths of the trawl- (w) and jigger-caught (h) squids being equal: $\mathrm{H}_{\mathrm{o}}: \mathrm{L}_{\mathrm{t}}=\mathrm{L}_{\mathrm{j}}$. The alternative hypothesis states that the mean length of the trawl-caught squids is less than the mean length of the jigger-caughts ones, $\mathrm{H}_{1}: \mathrm{L}_{\mathbf{t}}<\mathrm{L}_{\mathrm{j}}$.

For the data grouped by the gear type into two closed sets, the results of the test suggested rejection of the null hypothesis and acceptance of the alternative hypothesis of the mean length of the trawl-caught I.argentinus being lower than that of the jigger-caught ones. When the individual 32 trawl-jigger pairs of data were tested, the null hypothesis of equality of the means could be accepted for 15 and 14 pairs of male and female data, respectively.

The difference between lengths of jigger-caught Illex relative to those of trawl-caught ones can be expressed by a linear regression equation in the form of $\mathrm{L}_{j}=a+\left(\mathrm{L}_{t} * b\right)$ in which

- $\mathrm{a}=0.73388, \mathrm{~b}=0.99145, \mathrm{r}=0.988, \mathrm{R}^{2}=97.6 \%$ for males;

- $a=2.85188, b=0.91895, r=0.914, R^{2}=83.5 \%$ for females;

- $\mathrm{a}=0.81472, \mathrm{~b}=0.99555, \mathrm{r}=0.948, \mathrm{R}^{2}=89.9 \%$ for all squids.

The regression lines and the scatterplot of data are shown in Fig. 7. The table below and Fig. 8 present the ranges of differences in length of the jigger-caught squids relative to the trawl-caught ones in selected length classes. 


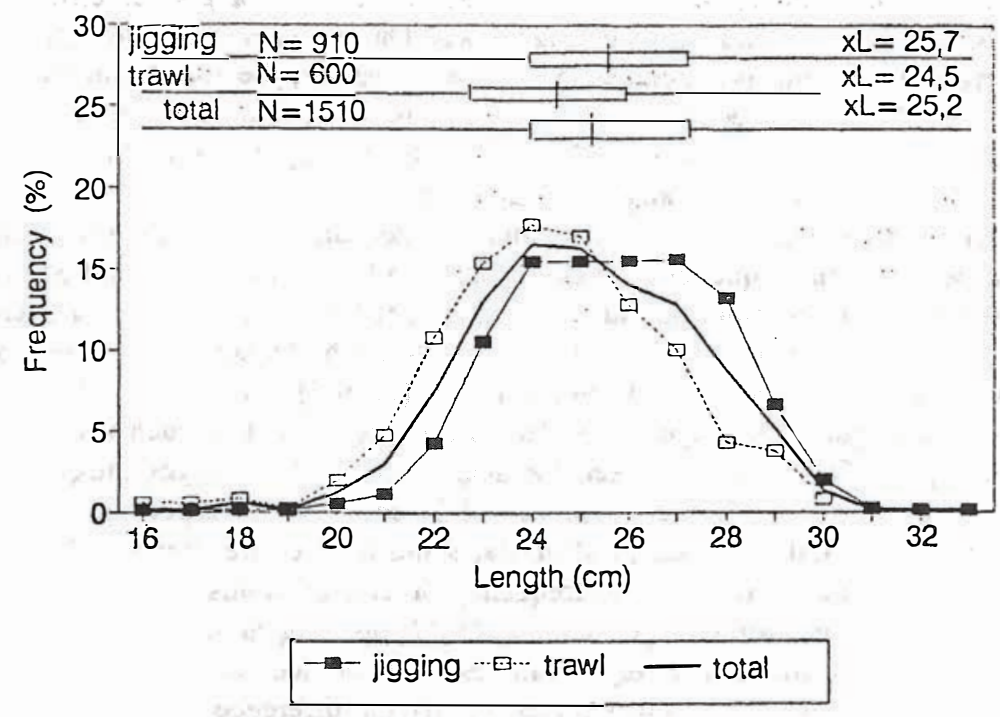

Fig. 3.Length distribution of trawi and jigging caught Illex argentinus females

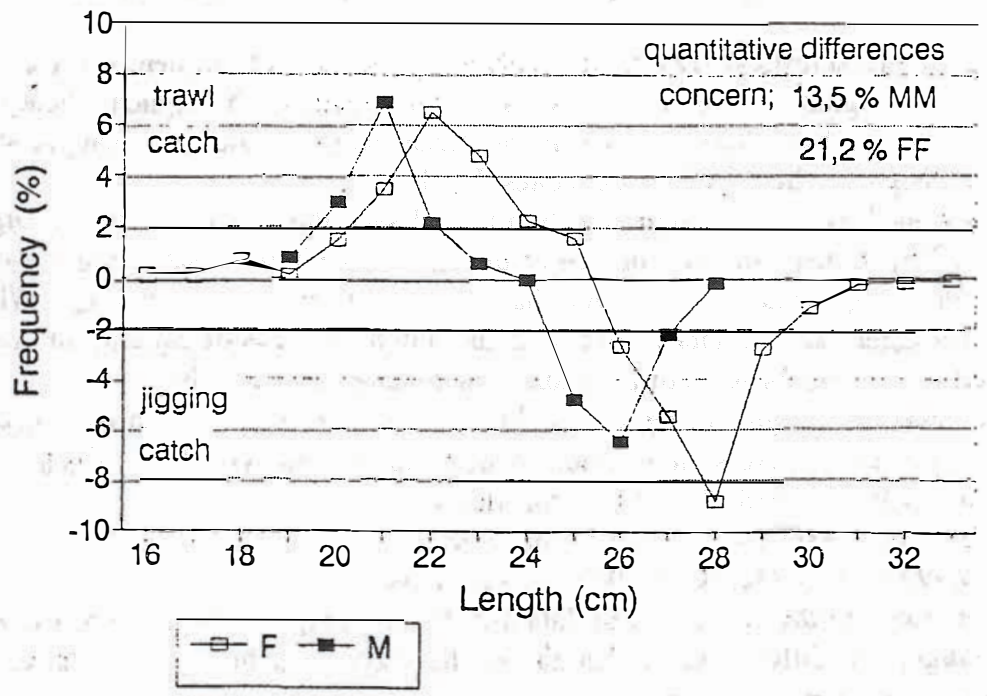

Fig. 4. Differences in frequencies of males $(\mathrm{M})$ and females $(\mathrm{F})$ in trawl and jigging catches 


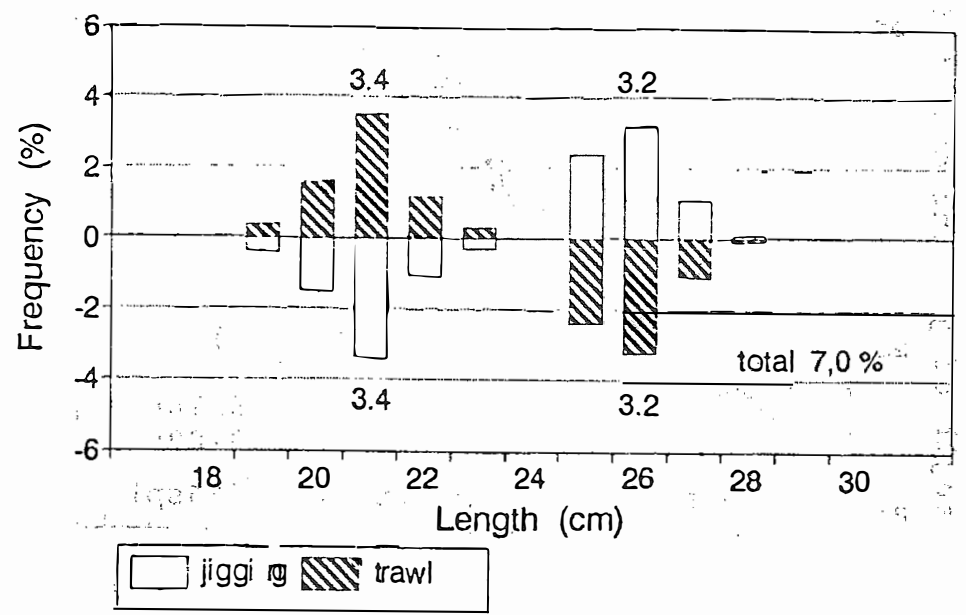

Fig. 5. Differences in frequencies of trawl and jigging caught males relative to averaged frequencies in pooled samples

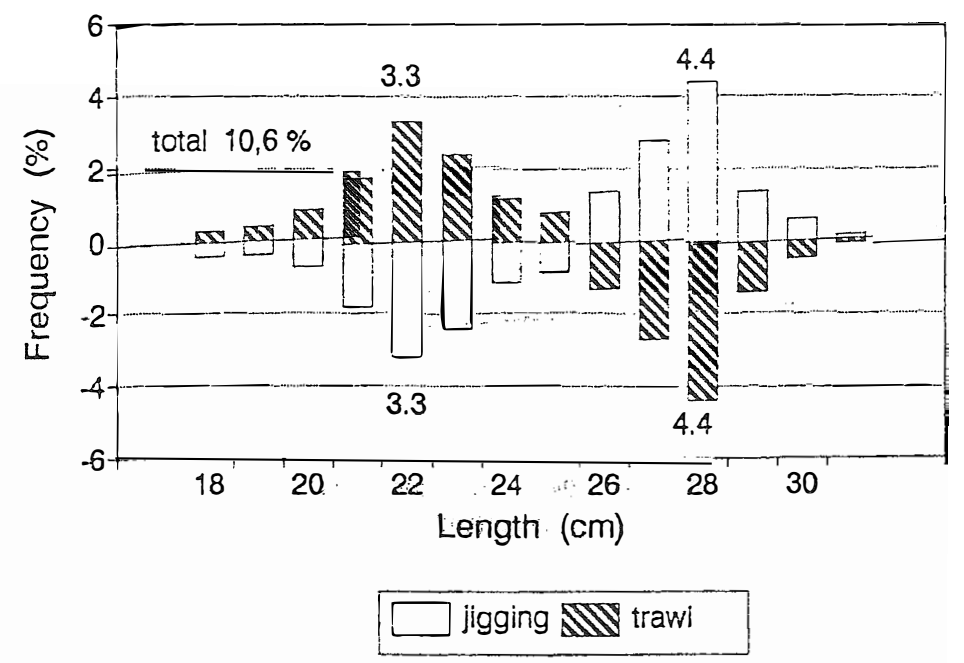

Fig. 6. Differences in frequencies of trawl and jigging caught females relative to averaged frequencies in pooled samples: 


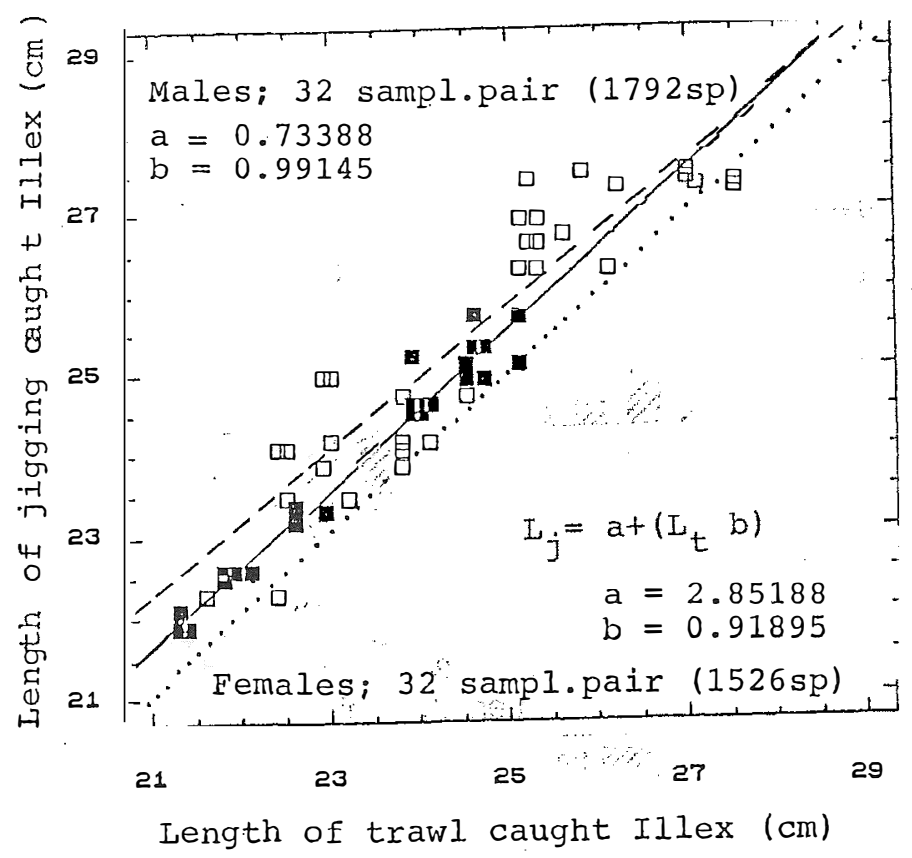

Fig. 7. Relationship between mean length of jigging caught Illex males (filled squares, solid line) and females (empty squares, dashed line) and mean length of trawl caught individuals as described by a linear regression

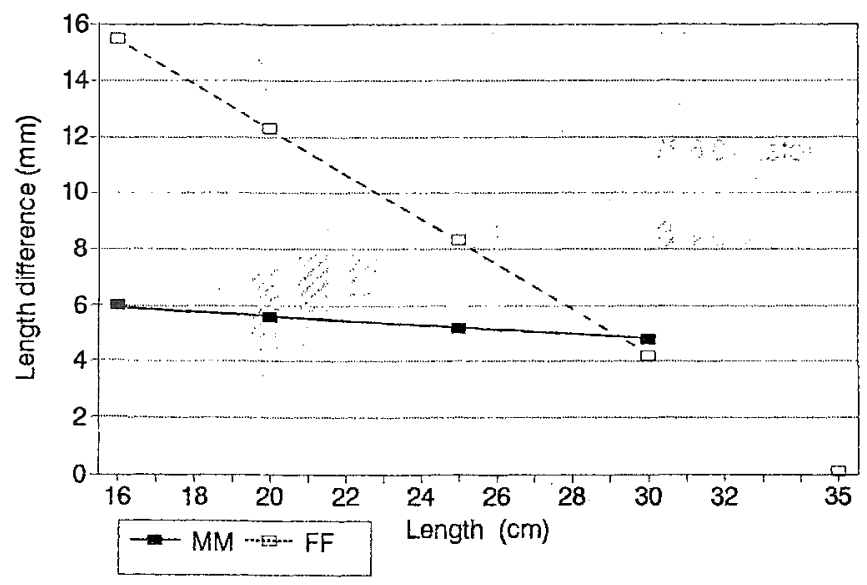

Fig. 8, Length difference between jigging caught males $(\mathrm{M})$ and females $(\mathrm{F})$ relatively to trawl caught individuals 


\begin{tabular}{|c|c|c|c|c|c|c|}
\hline $\begin{array}{c}\text { Trawl-caught squids: } \\
\text { mean lenght }\end{array}$ & \multicolumn{5}{|c|}{ J i g g e r - c a u g h t s q u i d s } \\
& \multicolumn{2}{|c|}{ males } & \multicolumn{2}{c|}{ females } & \multicolumn{1}{c|}{ all squids } \\
\cline { 2 - 7 } & $(\mathrm{cm})$ & $(\%)$ & $(\mathrm{cm})$ & $(\%)$ & $(\mathrm{cm})$ & $(\%)$ \\
$(\mathrm{cm})$ & 0.60 & 3.6 & 1.55 & 8.80 & 0.74 & 4.4 \\
16 & 0.56 & 2.7 & 1.23 & 5.60 & 0.73 & 3.5 \\
20 & 0.52 & 2.0 & 0.83 & 3.20 & 0.70 & 2.7 \\
25 & 0.48 & 1.6 & 0.42 & 1.40 & 0.68 & 2.2 \\
30 & 0.43 & 1.2 & 0.01 & 0.03 & 0.66 & 1.8 \\
35 & 0.70 & 2.0 & 1.20 & 2.50 & - & - \\
\hline
\end{tabular}

As seen from the above data, the largest differences concern the smallest squids and diminish as the squids grow. For all practical reasons, and considering the length classes of frequencies exceeding $1 \%$, it can be assumed that the difference among males was constant and amounted to $5 \mathrm{~mm}$ over the entire length range $(20-28 \mathrm{~cm})$. Among the females, the difference decreased from 12 to $4 \mathrm{~mm}$ over the length range of $20-30 \mathrm{~cm}$. No $30 \mathrm{~cm}$ long females occurred in trawl catches (Figs 2, 3, 7, 8).

\section{Sexua 1 maturity}

The distribution of maturity stages in both sexes is presented in Fig. 9. The frequency patterns show no relation to the gear type. Only the maturing and mature stages were present among the males which mature earlier than the females. The overall mean maturity stage of males was 4.94, 4.92 and 4.96 being the respective means for trawl-and jigger-caught males.

Among the females, the immature, preparatory and maturing stages were represented. The overall mean maturity stage of females was $2.30,2.23$ and 2.35 being respective means for trawl-and jigger-caught females.

The length disuributions by maturity stage of trawl-and jigger-caught males and females are shown in Fig. 10, while the table below summarises differences between the mean length at each stage in trawl and jigger catches relative to the means of pooled samples:

\begin{tabular}{|l|c|c|c|c|c|}
\hline \multirow{3}{*}{$\begin{array}{c}\text { Sex and maturity } \\
\text { stage }\end{array}$} & \multicolumn{5}{|c|}{ Mean length in: } \\
\cline { 2 - 6 } & $\begin{array}{c}\text { Pooled sample } \\
\text { trawl catches }\end{array}$ & \multicolumn{2}{c|}{ jigger catches } \\
\hline & 1 & 2 & $2-1$ & 3 & $3-1$ \\
\hline Males 4 & 20.7 & 20.5 & -1.0 & 21.2 & +2.4 \\
Males 5 & 23.6 & 23.3 & -1.3 & 23.9 & +1.3 \\
Females 2 & 24.5 & 23.9 & -2.4 & 24.9 & +1.6 \\
Females 3 & 26.7 & 26.2 & -2.0 & 27.0 & +1.0 \\
Females 4 & 28.3 & 27.5 & -2.8 & 28.6 & +1.1 \\
\hline
\end{tabular}

The jigger-caught squids of all maturity stages were larger (stage 4 males by $7 \mathrm{~mm}$; stage 5 males by $6 \mathrm{~mm}$; stage 2 females by $10 \mathrm{~mm}$; stage 3 females by $8 \mathrm{~mm}$; stage 4 females by 11 $\mathrm{mm}$ ) than the trawl-caught ones (Fig. 9). 


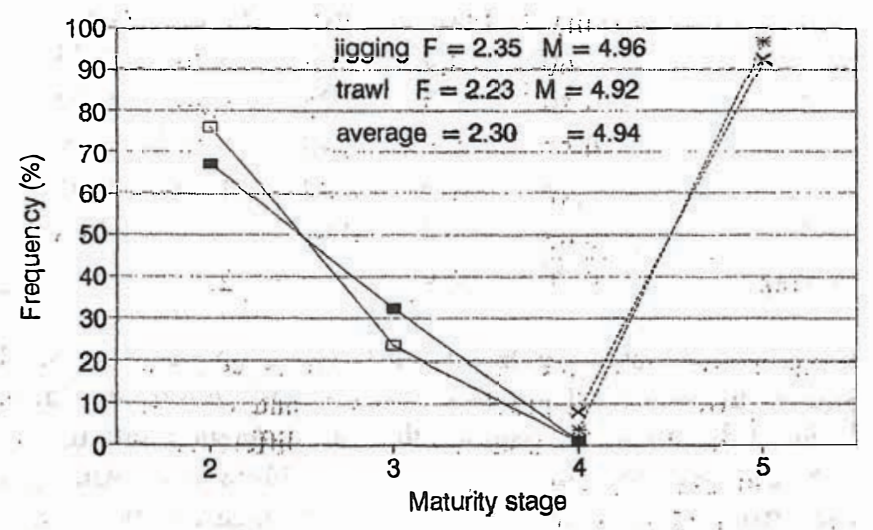

$\rightarrow-F-j-E-F-t-\cdots-M-j \cdot-x-M-t$

Fig. 9 Maturity stage distribution of males (M) and females (F) caught with trawl $(t)$ and jigging (j)
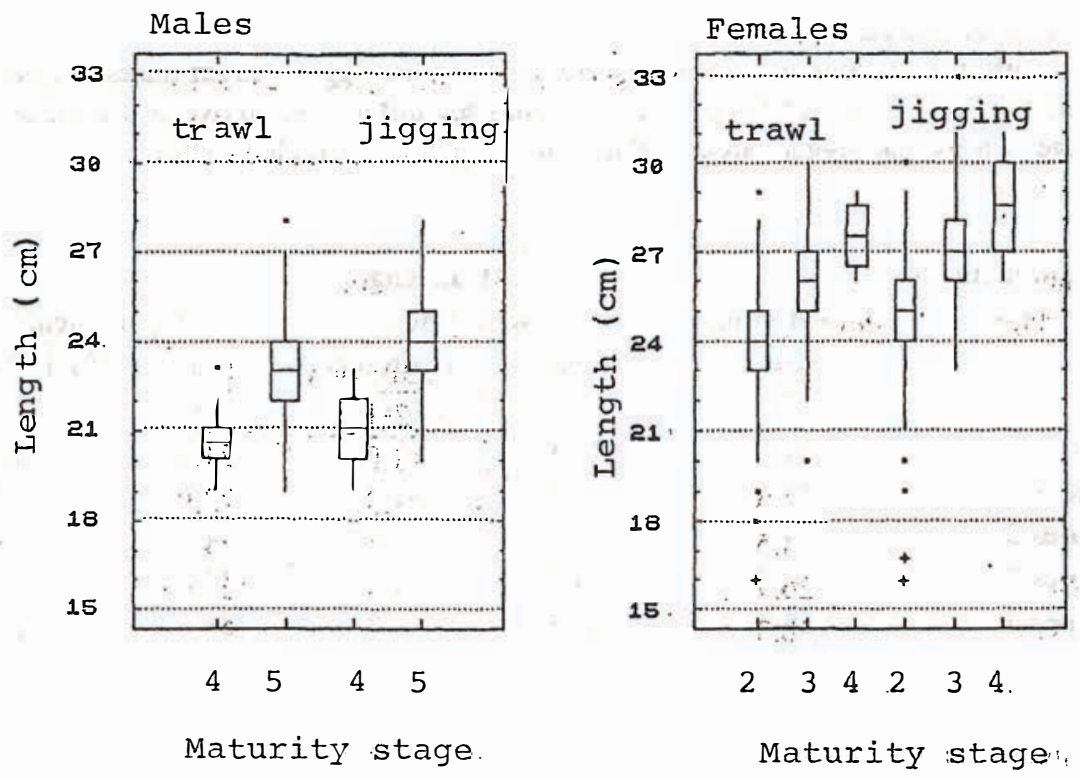

Fig. 10 Length structure of jigging and trawl caught males and females by miduturity stage 


\section{S ex ratio}

In the pooled sample of the I.argentimus caught, the proportions of males $(53.9 \%)$ and females $(46.1 \%)$ were at equilibrium, the sex ration becoming 1:17:1 (Fig. 1). Males were found to be more numerous in the trawl catches; the proportion of males $(63.6 \%)$ corresponds to the sex ratio of $1.75: 1$ (Fig. 2). On the other hand, females were more numerous in the jigger catches in which the female contribution of $56.0 \%$ corresponds to the sex ratio of $1.27: 1$ (Fig. 3).

\section{DISCUSSION}

The question of gear selectivity and catch ability involves a number of issues related to effects of technological, environmental, and biological factors on the qualitative and qualitative characteristics of a target species. This paper emphasises the qualitative differences between biological characteristics of squids caught commercially with two totally different types of gear, i.e., the trawl and jiggers. The basic assumption expounded here is that trawling, as a forced sampling technique, provides a random and representative sample of the Illex argentinus population. The fine-mesh insert the trawl was equipped with was additionally ensuring that this was indeed the case. Thus one can content that the trawl was capable of catching the full size range of the Illex present.

On the other hand, the squids are attracted to the artificial bait mounted on jiggers and thus the behavioural responses of the squids are taken advantage of when jigging. The responses may depend on the squid size, sex, and/or maturity stage. When determining the catch ability of jiggers, the absolute catch ability [Radtke 1993] is taken into account, the population model being furnished by the trawl catch.

In jigging operations, there is an inevitable primary source of jigger selectivity, determined by the squid weight. This is an important factor in species reaching an individual weight of more $\tan 2-3 \mathrm{~kg}$. Although such squids do take the jiggers, their tentacles get detached due to the weight of the body and the squids fall bask to the water. Consequently, the size structure of jigger-caught squid catch will be decidedly different from that emerging from, e.g., catches effected by stationary nets. This has been observed and described for harvesting large oceanic squids such as Dosidicus gigas and Ommastrephes bartrami [Araya 1983; Collins and Dunning 1981; Klett 1981; Koronkiewicz 1987,1989]. With respect to the latter, the catch ability was also affected by autonomy, i.e., an active rejection of tentacles by the squids, particularly the large individuals. The present author has observed some of the largest Illex, heavier than $1 \mathrm{~kg}$, to detach themselves from the jiggers, the squids being additionally weighed by the water filling their mantles.

Another aspect of jigger catch ability is related to the technical characteristics of the gear. The problem has been dealt with by, i.a., Blady [1994] who found the shelf and oceanic types of jiggers to differ in their catch ability. He also demonstrated the importance of the jigger colour; however, he did not study the ensuing variability in the size structure and sexual maturity of the Illex.

As mentioned before, this study was based on the commercial harvesting operations. The jigger sets used had thus been predetermined, in terms of their type, number per set, or colour, by practical considerations. No correction for the jigger configuration has been introduced on the assumption that any possible quantitative change resulting from the jigger structure would be based in a consistent manner and thus the qualitative changes are the significant indication of different catch abilities of the two types of gear. 
The different nature of the qualitative structure of the jigger-catch Illex vs. the trawl-catch ones should be predominantly associated with differences in feeding behaviour of males and females. Due to size and sexual maturity differentiation, caused by a higher growth rate and lower maturation rate of females, males and females differ in their feeding activity: , Generally during their on feeding migrations, when the Illex are feeding on the lobster-krill concentrations, they are best caught with jiggers. At that time (March and April), most males are mature, while the females are still dominated by immature and preparatory females. The females are the most active feeders, as confirmed by their prevalence $(56 \%)$ in jigger catches. As they mature, the Illex move to inhabit the deeper waters overlying the slope and cease to perform diurnal vertical migrations. They continue to fed, but switch to feeding on the myctophid fish. Additionally, cannibalism becomes important in their feeding habits. At that stage their life cycle, I.argentinus are available to trawling operations only.

From the biological point of view, the observed differences are indicative of different behaviour of males and females, and of different maturity stages in the case of females. As shown by the results, this has significantly affected the size distribution in half of the samples; in the other half, the differences were slight only, even from a statistical point of view. In both cases the distribution was normal; application of jiggers resulted only in higher frequencies in the upper part of the size range.

Similar differentiation of length structure as a result of selective interaction of jigger catch was found concerning squids Loligo vulgaris reynaudii sampled by jigging, midwater trawling and purse-seining [Lipinski 1994]. The author quated that the selectivity curve indicates that squid's lengths are over-represented in fisheries conduced by jigging and that squid are under-represented if purse-seine result are considered to be representative of the population.

The second important aspect of theme in question is practise dimension of ascertained selectivity. It's unquestionable that results obtained by catches both experimentally and commercially concern only the exploited part of the population, which is always in a form of dynamic apparition smaller and less maturity and emigration bigger and more mature specimens [Koronkiewicz 1986; Koronkiewicz and Porębski 1990]. However, the aim of the surveys made, is to describe the size of the biomass of the exploited stocks. The most advisable methods such as hydro-acustic or tag-recapture are not commantly used as not likely to be successful or because of the high cost. Practical consequences of the jigger catch ability demonstrated are another important aspect. Both Polish and foreign studies on squids were based on mixed data obtained from trawl and jigger catches. As the range of differences for all variables compared was confined to $5 \%$ for all practical purposes the differences can be regarded as small and hardly significant, particularly with respect to a collective analysis of data. Much greater differences have been recorded on many occasion in the practise of Illex research, e.g., following a slight change in the vessel's position or 1-2 days after a storm. Within the same geographical region, there is a difference between the squids inhabiting shelf water and those living above the slope. Thus one may conclude that the selectivity of jiggers is more important for the biological assessment of the squids than for deciding whether the materials are representative or not. While the existance of differential catch ability of jiggers, discussed in this paper from many angles, has to be acknowledged, there is no need for corrections when summarising trawling and jigging catch data, particularly with respect to characterising individual fishing, months or seasons of harvest. 


\section{CONCLUSIONS}

1. In all the samples, length data of Illex argentinus obtained from commercial trawl and jigger catches had a normal distribution. The jigger-caught Illex were larger than those caught by trawling by $7 \mathrm{~mm}$ (males), and $12 \mathrm{~mm}$ (females), on the average.

2. Jiggers affected the behavioural responses of the squids and resulted in higher frequencies of larger individuals, those frequencies being higher by:

$-13.5 \%$ in $25-28 \mathrm{~cm}$ long males, the general range being $19-28 \mathrm{~cm}$ in jigger and trawl catches;

$-21.2 \%$ in $26-33 \mathrm{~cm}$ long females, the general ranges being $16-33 \mathrm{~cm}$ and $16-30 \mathrm{~cm}$ in jigger and trawl catches, respectively.

3. Size differences between the trawl and jigger caught I.argentinus were statistically significant in $53 \%$ and $56 \%$ of samples of males and females, respectively. In the remaining samples, mean lengths of the squids caught with jiggers and the trawl were not significantly different.

4. Differences between the jigger-and trawl-caught squids lengths can be described with a linear regression equation in the form of $\mathrm{L}_{\mathrm{j}}=\mathrm{a}+\left(\mathrm{L}_{\mathrm{t}} * \mathrm{~b}\right)$ with

- $a=0.73388, b=0.99145, r=0.988, R^{2}=97.6 \%$ for males;

- $\mathrm{a}=2.85188, \mathrm{~b}=0.91895, \mathrm{r}=0.914, \mathrm{R}^{2}=83.5 \%$ for females;

- $a=0.81472, b=0.99555, r=0.948, R^{2}=89.9 \%$ for all squids.

5. The jigger-caught Illex were more mature than those caught with the trawl by $0.8 \%$ (males) and $5.1 \%$ (females), on the average, the percentages referring to differences between mean maturity stages.

6. From the biological point of view, the differences observed result from a different feeding behaviour of males and females, and from different maturity stages in females. Immature females (stages 2 and 3 ) which are the most active feeders were found to dominate, contributing $56 \%$ of the abundance on the average, in the jigger catches.

7. For all practical purposes, at the slight differences between the biological characteristics of the Illex caught with two different methods, there is no need to correct the data when preparing overall summaries of trawl and jigger catches.

\section{REFERENCES}

Araya Hisao, 1983: Fishery, biology and stock assessment of Ommastrephes bartrami in the North Pacyfic Ocean, Memoris of the National Museum Victoria, 44, 269-283.

Arkhipkin A.Io: Zh.N.Scherbich, 1991: Crecimiento y estructura infraspecifica del calmar, Illex argentinus (Castellanos 1960) (Ommastrephidae) en invierno y primavera en el Atlantico sudoccidental. Sci. Mar. 55(4), 619-627.

Basson M., J.R.Beddington, J.A.Crombie, S.J.Holden, L.V.Purchase, G.A.Tinglej, 1993: Assessment and management techniques for migratory annual squid stock: The Illex argentinus fishery in the Southwest Atlantic as an example. Renewable Resources Assessment Group, Imperial College, London, manuscript, 1-25.

Blady W., 1994: Wpływ różnych czynników na zdolność połowową trawlerów stosujących wędy kalmarowe. [Influence difference of agents for catchebility of trawlers used the jiggers, Qualifying thesis]. Sea Fisheries Research Institute in Gdynia, manuscript, (In Polish). 
Brunetti N.E., 1980: Distribution de tallas y biologia reproductiva del calamar (Illex argentinus) en el mar Argentino (Camapanas del B/I "Shinakai man", 1978-1979). Instituto Nacional de Investigacion y Desarrollo Pesquero; becaria de la Comision de Investigationes Cientificas de la Prov. de Bs. Aires, Campanas de investigation pesquera realizadas en el mar Argentino, 119-127.

Brunetti N.E., M.L.Ivanovicz, 1992: Distribution and abundance of early life stages of squid (Illex argentinus) in the south-west Atlantic. ICES J. Mar. Sci., 49, 175-183.

Castellanos $\mathbb{Z}$., 1960: Una nueva especie de calamar argentino Ommastrephes argentinus sp. nov. (Mollusca: Cephalopoda). Neotropica, La Plata, 6(20), 55-58

Collins S., M.Dunning, 1981: Tasman squid studies demonstrate gillnetting effective. Australian Fisheries, August, 1981.

Hatanaka H., 1986: Growth and life span of short-finned squid Illex argentinus in the waters of Argentina. Biulletin of the Japanese Society of Scientific Fisheries Tokyo,52(1), 11-17.

Holden M.J., D.F.S.Rait, 1974: Manual of fisheries science. Part 2, Methods of resource investigation and their application. FIRS/T 115 (Rev. 1) FAO, ROME.

Klett A., 1981: Jumbo squid fishery in the Gulf of California Mexico. Centro de Ivestigaciones Pesqueras de la Paz, Mexico, Manuscript, 1-20.

Martinez J., N.P.Contreras, V.Trujillo, 1991: Reproduktive aspectos of Loligo gahi, Illex argentinus and Marluccius hubbsi. Manuscript, Instituto Espanol De Oceanografia, Centro Oceanografico de Vigo, 1-29.

Matthews L.H., 1932: Lobster-krill anomuran crustacea that are the food of whales. Discovery Reports At the University Press, Cambridge. Vol. V, 467-484, .

Koronkiewicz A., 1985: Ocena biologiczno-rybacka kalmarów Illex argentinus na szelfie argentyńskim (poza strefą $200 \mathrm{Mm}$ Argentyny) w okresie 1980-1985. [The report of biological and fishery state of squid Illex argentinus (Cephalopoda: Ommastrephidae) on the open water Argentinian Shelf, 1980-1985]. Sea Fisheries Research Institute, Branch in Świnoujście, manuscript, 1-27, (In Polish).

Koronkiewicz A., 1986: Growth and life cycle of the squid Illex argentinus from the Patagonian shelf and Polish squid fishery in this region, 1978-1985. ICES Shel. Com. C.M. K:27, 1-25.

Koronkiewicz A., 1987: Sprawozdanie z prac przemysłowego zwiadu kalmarowego (wędowe połowy kalmarów Dosidicus gigas) przeprowadzonych na m/t "Jasień" w okresie 26.10-12.12.1986 na wodach Srodkowo-wschodniego Pacyfiku poza strefa $200 \mathrm{Mm}$. [The report of jigging fishery (Dosidicus gigas: Cephalopoda, Ommastrephidae) by m/t "Jasień" in period 26.10.-12.12.1986 in open water Central-East Pacific]. sea Fisheries research Institute, Branch in Świnoujście, manuscript 1-32, (In Polish).

Koronkiewicz A., 1989: Sprawozdanie z pławnicowych połowów kalmarów i ryb na wodach Północno i Środkowo-Wschodniego Pacyfiku w okresie od 6.11.1988 do 11.04.1989. [The report of jill-net fishery in Nord- and central-East Pacific, 6.11.1988-11.04.1989, Sea Fisheries Research Institute]. Branch in Świnoujście, manuscript, 1-37, (In Polish).

Koronkiewicz A., J.Porębski, 1990: Charakterystyka eksploatacji oraz stanu biologicznego kalmarów Illex argentinus i Loligo gahi łowionych w latach 1986-1990 na łowiskach Pd-Zach Atlantyku. [The fishery and biological state characterization of squids Illex argentinus and Loligo gahi (Cephalopoda: Ommastrephidae and Loliginidae) in 1986-1990 in South-West Atlantic. Sea Fisheries Research Institute, Branch in Świnoujście, manuscript, 1-30, (In Polish). 
Koronkiewicz A., 1991: Biologiczno-rýbacka charakterystyka kalmarów Illex argentinus. Sprawozdanie $\mathbf{z}$ obserwacji przeprowadzonych na $\mathrm{mt}$ "Garnela" w okresie 30.03.-12.07.1991. [The biological characterization and fishery of squids Illex argentinus (Cephalopoda: Ommastrephidae). report of expedition $\mathrm{mt}$ "Garnela" in period 30.03.-12.07.1991]. Sea Fisheries Research Institute, Branch in Swinoujście, manuscript, 1-30, (In Polish).

Lipiński M., 1979: Universal maturity scale for the commercially important squids. The results of maturity classification of Illex illecebrosus population for the years 1973-1977. ICNAF Research Document 79/2/38, Serial 5364, 1-40.

Lipiński M., 1994: Differences among basic biological parameters in a population of Chokka squid Loligo vulgaris reynaudii (Cephalopoda: Loliginidae) sampled by three methods, Sea Fisheries Research Institute in Gdynia, manuscript, 1-10.'

Oktaba W., 1974: Elementy statystyki matematycznej i métodýka doświadczalnictwa, wydanie trzecie PWN. [The elements of mathematical statistics and methodics of experimentation]. III edition, State Scientific Publishers, Warszawä, (In Polish).

Wolnomiejski N., 1985: Sprawozdanie z biologiczno-eksploátacyjny ch obserwacji kalmarów Illex argentinus przeprowadzonych na mt "Gopło" w rejonie Pd-Zach. Atlantyku (z okresu połowowego 15.02.-26.05.1985. [Report of the biological and catch observation of squids Illex argentinus (Cephalopoda: Ommastrephidae) realized on the "int "Gopło" in South-west Atlantic, 15.02.-26.05.1985]. Sea Fisheries Research Institute, Branch in Świnoujście, manuscript, 1-30, (In Polish).

Wolnomiejski N., 1986: Biologiczno-eksploatacyjna charakterystyka kalmarów (Illex argentinus i Martialia hyadesi) Pohudniowo-Zachodniego Atlatityku. [The biological and catch characterization of squids Illex argentinus and Martialia hyddesi (Cephalopoda: Ommastrephidae) in South-West Atlantic]. Sea Fisheries Research Institute, Branch in Świnoujście, manuscript, 1-32, (In Polish).

Wolnomiejski N., 1992: Biologiczno-eksploatacyjna charakterystyka kalmarów Illex argentinus w sezonie 1991. [The biological and catch characterization of squids Illex argentinus (Cephalopoda: Ommastrephidae) in 1991 season]. Sea Fisheries Research Institute, Branch in Świnoujście, manuscript, 1-24, (In Polish).

Wysokiński A., 1992: Charakterystyka stada kalmara Loligo gahi w rejonie Wysp Falklandzkich w sezonie polowowym 1992. [Characterization of the Loligo gahi (Cephalopoda: Loliginidae) stock in Fallkland Islands region in 1992 season]. Sea Fisheries Research Institute, Branch in Świnoujście, manuscript, 1-40, (In Polish).

Translated by: Dr Teresa Radziejewska 
Andrzej KORONKIEWICZ :

\section{PORÓWNANIE STRUKTURY DEUGOŚCIOWEJ I DOJRZAEOŚCI PŁCIOWEJ KALMARÓW ILLEX ARGENTINUS (CASTELLANOS, 1960) ZŁOWIONYCH WEDAMI I WŁOKIEM}

\section{STRESZCZENIE}

Niniejsze rozważania podjęto w celu wyjaśnienia, w jakim stopniu, uwzględniając główne parametry populacyjne, kalmary. Illex argentinus (ileksy) złowione hakami różnią się od ileksów złowionych włokiem. Ileksy: pochodziły z przemysłowych połowów, włokiem i hakami, dokonanych 4-15, 24-25 i 28-31 marca oraz 2 i 7-11 kwietnia 1992r. w rejonie ileksowego sektora Falkland Interim Conservation Zone.

Porównując strukture długościową kalmarów Illex argentinus złowionych włokiem i hakami, stwierdzono, że kalmary złowione hakami były większe od kalmarów złowionych włokiem średnio o $7 \mathrm{~mm}$ (samce) i o $12 \mathrm{~mm}$ (samice). Haki oddziałujące na behawioralne reakcje ileksów wpływały na zwiększenie frekwencji większych osobników o 13.5\% wśród samców (w zakresie $25-28 \mathrm{~cm}$, przy ekstremalnych długościach $19-28 \mathrm{~cm}$ ) oraz o. $21.2 \%$ wśród samic (w zakresie 26-33 cm, przy ekstremalnych dhugościach 16-33 cm). Różnice dhugości kalmarów złowionych hakami w stosunku do długości kalmarów złowionych włokiem maja charakter funkcji prostoliniowej. Kalmary złowione hakami były bardziej dojrzałe płciowo od kalmarów złowionych włokiem - średnio o $0.8 \%$ (samce) i o $5.1 \%$ (samice).

Received: 1994.07.01

Author's address:

M.Sc. Andrzej Koronkiewiç

Sea Fisheries Institute Branch in Świnoujście

Plac Słowiański 11

72-600 Świnoujście

Polska (Poland) 